\title{
A ORDEM ECONÔMICA CONSTITUCIONAL E OS LIMITES À ATUAÇÃO ESTATAL NO CONTROLE DE PREÇOS
}

\author{
LUÍS ROBERTO BARROSO*
}

\begin{abstract}
Parte I - CONSTITUIÇÃO, ORDEM ECONÔMICA E INTERVENÇÃO ESTATAL - I. Fundamentos da ordem econômica: livre iniciativa e valorização do trabalho humano - II. Princípios da ordem econômica - II.1. Princípios de funcionamento - II.2. Princípios-fins - III. Agentes da ordem econômica - III.1. Papel do Estado na ordem econômica - III.2. Papel da iniciativa privada na ordem econômica - IV. Intervenção estatal na ordem econômica: disciplina - IV.1. Modalidades de intervenção estatal na ordem econômica - IV.2. Limites e fundamentos legítimos da intervenção disciplinadora - a) Limites da disciplina - b) Fundamentos da disciplina - Parte II - LIMITES CONSTITUCIONAIS À DISCIPLINA DE PREÇOS - POR PARTE DO ESTADO - V. Competência estatal em matéria de preços privados - V.I. A livre fixação de preços é elemento fundamental da livre iniciativa. $O$ controle prévio de preços como política pública regular viola princípio constitucional - V.2. Somente em situação de anormalidade do mercado, ausentes as condições regulares de livre concorrência, o princípio da livre iniciativa poderá sofrer ponderação para admitir o controle prévio de preços - V.3. Pressupostos constitucionais para o controle prévio de preços - VI. Conclusão
\end{abstract}

O estudo que se segue encontra-se dividido em duas partes. Na parte I, procura-se delinear doutrinariamente o papel econômico do Estado e seus limites legítimos. Na parte II, desenvolve-se o estudo das possibilidades e limites da ação estatal no que diz respeito a preços privados em geral. Doze anos após a reconstitucionalização,

* Participaram da pesquisa e da discussão das idéias expostas neste trabalho Ana Paula de Barcellos e Nelson Nascimento Diz.

Professor Titular de Direito Constitucional da UERJ. Professor de Direito Constitucional Econômico da FGV. Mestre pela Universidade de Yale. Advogado no Rio de Janeiro.

R. Dir. Adm.,

Rio de Janeiro, 226: 187-212,

out./dez. 2001 
estes temas ainda suscitam perplexidades diversas e não foram pacificados na doutrina, na jurisprudência e na prática dos Poderes públicos.

Doutrinadores eminentes sustentam o ponto de vista de que, no Brasil, após a Constituição de 1988, não mais seria legítimo qualquer tipo de atuação estatal no controle de preços, à vista do princípio da livre concorrência ${ }^{1}$. Há um conjunto bem articulado de argumentos em favor dessa tese, sem embargo de existir pronunciamento jurisprudencial relevante em sentido diverso ${ }^{2}$. Cabe-me declinar, por dever de honestidade científica, que não é esta a minha convicção, consoante externei em artigo doutrinário escrito ainda em $1993^{3}$.

De fato, não tendo o princípio caráter absoluto, pode haver situações excepcionais de intervenção estatal legítima em matéria de preços. Esta possibilidade, eventual e drástica, não se confunde com a idéia que tem ganho curso em certos segmentos governamentais: a de que a livre iniciativa, decisão política fundamental do constituinte de 1988, deva ceder passo diante de todos os demais bens em alguma medida valorados pela Constituição. Ou pior: deve submeter-se às decisões circunstanciais da conveniência política.

A questão é complexa e será objeto de apreciação analítica, em um esforço para delimitar o espaço próprio de irradiação de cada um dos princípios relevantes, bem como dos parâmetros dentro dos quais os juízos de ponderação deverão operar. A trajetória delineada inclui a análise de aspectos jurídico-constitucionais da ordem econômica e do papel reservado à iniciativa privada e ao Estado, com ênfase nos fundamentos e limites da intervenção disciplinadora do Poder Público sobre a atuação privada.

1 Essa é a posição, dentre outros autores, de Diogo de Figueiredo Moreira Neto, Ordem econômica e desenvolvimento na Constituição de 1988, 1989, p. 69/70; Celso Ribeiro Bastos, Comentários à Constituição do Brasil, 1990, p. 16/17; Miguel Reale Júnior, Casos de direito constitucional, 1992, p. 18/19; Marcos Juruena Villela Souto, Constituição econômica, Cadernos de direito tributário 4, 1993, p. 250 e Dinorá Adelaide Muselli Grotti, Intervenção do estado na economia, Revista dos Tribunais - Cadernos de Direito Constitucional e Ciência Política n ${ }^{\circ}$ 15, 1996, p. 74.

2 Trata-se da decisão do Supremo Tribunal Federal na ADIN no 319-DF que, por maioria, considerou constitucional a Lei $\mathrm{n}^{\circ} 8.039 / 90$, que dispunha sobre critérios de reajustes das mensalidades escolares. Vale registrar que não se está integralmente de acordo com as premissas e conclusōes da referida decisão, que, excessivamente marcada pelas circunstâncias do caso concreto, não produziu fundamentos de validade geral.

3 Luís Roberto Barroso, A crise econômica e o direito constitucional, in Revista Forense $n^{\circ} 323 / 83$, p. 92: "A despeito do reconhecimento que merecem os autores citados — ambos da maior suposiçāo - parece-me radical o ponto de vista de que o princípio da livre concorrência veda, tout court, a possibilidade de o Govemo controlar preços, inclusive por tabelamento ou congelamento. É preciso ter em conta outros valores da ordem constitucional que atenuam a rigidez de tal colocação, como, v.g., a defesa do consumidor (art. 170, V) e a repressão do abuso do poder econômico que vise à dominação dos mercados, à eliminação da concorrência e o aumento arbitrário de lucros (art. 173, $\left.\S 4^{\circ}\right)^{\prime \prime}$. 
I. Fundamentos da ordem econômica: livre iniciativa e valorização do trabalho humano

A livre iniciativa e o valor do trabalho humano são dois dos princípios fundamentais do Estado brasileiro e os fundamentos da ordem econômica. Essa é a dicção expressa dos arts. $1^{\circ}$, IV, e 170, caput, da Carta, in verbis:

"Art.1". A República Federativa do Brasil (...) tem como fundamentos:

IV - os valores sociais do trabalho e da livre iniciativa;"

"Art. 170. A ordem econômica, fundada na valorização do trabalho humano e na livre iniciativa (...)".

Tais princípios correspondem a decisões políticas fundamentais do constituinte originário ${ }^{4} \mathrm{e}$, por essa razão, subordinam toda a ação no âmbito do Estado, bem como a interpretação das normas constitucionais e infraconstitucionais. A ordem econômica, em particular, e cada um de seus agentes - os da iniciativa privada e o próprio Estado - estão vinculados a esses dois bens: a valorização do trabalho [e, a fortiori, de quem trabalha,] e a livre iniciativa de todos - que, afinal, também abriga a idéia de trabalho - , espécie do gênero liberdade humana.

A Constituição de 1988 cuidou de concretizar o princípio da valorização do trabalho em regras concentradas em seu art. $7^{\circ}$, onde se pode encontrar um rol de direitos assegurados aos trabalhadores ${ }^{5}$. $O$ elenco que ali figura não exclui outros direitos que visem à melhoria de sua condição social, nos termos expressos do caput do mesmo artigo ${ }^{6}$. O constituinte prestigiou, nessa mesma linha, o trabalho dos autores e inventores, através das garantias do direito autoral (art. $5^{\circ}, \mathrm{XXVII}$ ) e da proteção patentária (art. $5^{\circ}, \mathrm{XXIX)}$ ), e daqueles profissionais que participam de espetáculos públicos ou de obras coletivas (art. $5^{\circ}, \mathrm{XXVIII)}$ ). O fundamento da proteção ao trabalhador e da valorização do trabalho encontra-se na própria dignidade da pessoa humana (art. $1^{\circ}$, III).

O princípio da livre iniciativa, por sua vez, pode ser decomposto em alguns elementos que lhe dão conteúdo, todos eles desdobrados no texto constitucional. Pressupõe ele, em primeiro lugar, a existência de propriedade privada, isto é, de apropriação particular dos bens e dos meios de produção (CF, arts. $5^{\circ}$, XXII e 170,

4 Sobre o conceito de decisōes políticas fundamentais, v. Carl Schmitt, Teoría de la Constitución, 1970.

5 Ainda que alguns permaneçam paralisados pela inércia do legislador.

$6 \mathrm{CF}$, art. $7^{\circ}$, caput: "São direitos dos trabalhadores urbanos e rurais, além de outros que visem à melhoria de sua condição social:". 
II). De parte isto, integra, igualmente, o núcleo da idéia de livre iniciativa a liberdade de empresa, conceito materializado no parágrafo único do art. 170 , que assegura a todos o livre exercício de qualquer atividade econômica, independentemente de autorização, salvo nos casos previstos em lei. Em terceiro lugar situa-se a livre concorrência, lastro para a faculdade de o empreendedor estabelecer os seus preços, que hão de ser determinados pelo mercado, em ambiente competitivo (CF, art. 170, IV). Por fim, é da essência do regime de livre iniciativa a liberdade de contratar, decorrência lógica do princípio da legalidade, fundamento das demais liberdades, pelo qual ninguém será obrigado a fazer ou deixar de fazer alguma coisa senão em virtude de lei (CF, art. $\left.5^{\circ}, \mathrm{II}\right)$.

É bem de ver que, embora a referência à livre iniciativa seja tradicional nos textos constitucionais brasileiros, a Carta de 1988 traz uma visão bem diversa da ordem econômica e do papel do Estado, em contraste com os modelos anteriores. Já não se concede mais, como fazia a Carta de 1967/69, ampla competência na matéria ao legislador ordinário, ao qual era reconhecida até mesmo a possibilidade de instituir monopólios estatais ${ }^{7}$. As exceções ao princípio da livre iniciativa, portanto, haverão de estar autorizadas pelo próprio texto da Constituição de 1988 que o consagra. Não se admite que o legislador ordinário possa livremente excluí-la, salvo se agir fundamentado em outra norma constitucional específica. ${ }^{8}$

Note-se desde logo que não há norma constitucional que autorize o estabelecimento de controle prévio de preços no âmbito do mercado. Apenas a atuação repressiva do Poder Público está constitucionalmente prevista, nos termos do art. $173, \S 4^{\circ}$ da Carta $^{9}$, a ser desencadeada a partir da apuração da prática de ilícitos em decorrência do abuso de poder econômico. É por essa razão que boa parte da doutrina rejeita qualquer forma de controle prévio de preços, como é o caso de Diogo de Figueiredo Moreira Neto, que registrou expressamente:

"É o caso para tocarmos num exemplo de grande importância, do controle estatal de preços. Essa prática, largamente utilizada no autoritarismo econômico, durante várias décadas neste País, mas tão prejudicial à competi-

7 Esse era o teor do art. 163 da Constituição de 1967/69: "São facultados a intervençāo no domínio econômico e o monopólio de determinada indústria ou atividade, mediante lei federal, quando indispensável por motivo de segurança nacional ou para organizar setor que não possa ser desenvolvido com eficácia no regime de competição e de liberdade de iniciativa, assegurados os direitos e garantias individuais.".

8 Nesse sentido, v. Diogo de Figueiredo Moreira Neto, Ordem econômica e desenvolvimento na Constituição de 1988, 1989, p. 69-70: "Este rol constitucional de instrumentos de intervenção regulatória é exaustivo: não admite ampliação por via interpretativa, uma vez que representam, cada um deles, uma exceção ao princípio da livre iniciativa (art. $1^{\circ}$, IV, e art. 170 , caput) e, mais precisamente, ao princípio da livre concorrência (art. 170, IV). Qualquer outra modalidade interventiva, admissível genericamente no art. $163 \mathrm{da}$ antiga Carta (...) perde, na vigente, seu suporte constitucional."

$9 \mathrm{CF}$, art. $173, \S 4^{\circ}$ : “A lei reprimirá o abuso do poder econômico que vise à dominação dos mercados, à eliminação da concorrência e ao aumento arbitrário dos lucros". 
ção, tão incompatível com uma política de desenvolvimento (hoje, princípio constitucional - art. $3^{\circ}$, II), tão perigosa pelas distorções que gera (como nos casos dos planos 'Cruzado' e 'Verão'), teve seu fim, com muito atraso, na Constituição de 1988. Não será mais possível à burocracia incompetente fazer demagogia com preços.

A intervenção regulatória nos preços não exclui, todavia, a modalidade sancionatória, sempre que se caracterizarem as transgressões previstas no art. 173, $\$ 4^{\circ}$, casos em que o Estado estará autorizado a intervir vinculada e motivadamente." 10

Tal ponto de vista, embora bem fundado e trazendo a autoridade de seu autor, não corresponde à minha conviç̧ão doutrinária, como já assinalado. Penso ser preciso conceder que, em situações excepcionais, o controle prévio de preços poderá justificar-se, com fundamento nos próprios princípios da livre iniciativa e da livre concorrência. Será este o caso quando esta medida extrema for essencial para reorganizar um mercado deteriorado, no qual esses dois princípios tenham entrado em colapso e não mais operem regularmente. De qualquer sorte, ainda nessa hipótese, o controle de preços somente será considerado legítimo se obedecer a um conjunto de pressupostos, que serão examinados adiante.

Cabe, nesse passo, uma breve anotação sobre a teoria dos princípios e como eles se inserem na ordem jurídica como um todo. Como já assinalado, nenhum princípio é absoluto. O princípio da livre iniciativa, portanto, assim como os demais, deve ser ponderado com outros valores e fins públicos previstos no próprio texto da Constituição. Sujeita-se, assim, à atividade reguladora e fiscalizadora do Estado, cujo fundamento é a efetivação das normas constitucionais destinadas a neutralizar ou reduzir as distorções que possam advir do abuso da liberdade de iniciativa e aprimorar-lhe as condições de funcionamento.

A ponderação é a técnica utilizada para a neutralização ou atenuação da colisão de normas constitucionais. Destina-se a assegurar a convivência de princípios que, caso levados às últimas conseqüências, acabariam por se chocar ${ }^{11}$. É o que acontece,

10 Diogo de Figueiredo Moreira Neto, Ordem econômica e desenvolvimento na Constituição de 1988 , 1989, p. 69/70. Essa é também a posição de muitos outros autores: Celso Ribeiro Bastos, Comentários à Constituição do Brasil, 1990, p. 16/17; Miguel Reale Júnior, Casos de direito constitucional, 1992, p. 18/19; Marcos Juruena Villela Souto, Constituiçāo econômica, Cadernos de direito tributário 4, 1993, p. 250 e Dinorá Adelaide Muselli Grotti, Intervenção do Estado na economia, Revista dos Tribunais - Cadernos de Direito Constitucional e Ciência Política $n^{\circ} 15$, 1996, p. 74.

11 Luís Roberto Barroso, Temas de direito constitucional, pp. 65-8: "O direito, como se sabe, é um sistema de normas harmonicamente articuladas. Uma situação não pode ser regida simultaneamente por duas disposições legais que se contraponham. Para solucionar essas hipóteses de conflito de leis, o ordenamento jurídico se serve de três critérios tradicionais: o da hierarquia (...), o temporal (...) e o da especialização (...). Esses critérios, todavia, não são satisfatórios quando o conflito se dá entre normas constitucionais. (...) A ponderação de valores é a técnica pela qual o intérprete procura lidar com valores constitucionais que se encontrem em linha de colisão. Como não existe 
e.g., com a liberdade de expressão e o direito à vida privada e à honra ou com o direito à propriedade e sua função social ${ }^{12}$. É evidente, entretanto, que a ponderação encontra limites no conteúdo próprio e típico de cada princípio. Não fosse assim, a interpretação constitucional seria um mero jogo de palavras sem conteúdo e sem valor. Bastaria afirmar que se está "ponderando" um determinado princípio para, por essa expressão mágica, o intérprete encontrar-se autorizado a transgredir livremente o que o princípio determina. Estar-se-ia diante de uma grande fraude à Constituição, finamente captada por Celso Antonio Bandeira de Mello:

"Um fundamento constitucional que pudesse ser arredado por obra de legislação ordinária ou um princípio que esta pudesse menoscabar, a toda evidência, nada valeriam e o constituinte seria um rematado tolo se houvesse pretendido construí-los com tal fragilidade." 13

Particularmente acerca da livre iniciativa e dos demais princípios que com ela convivem, escreveu ainda uma vez Diogo de Figueiredo Moreira Neto:

"O princípio da liberdade de iniciativa tempera-se pelo da iniciativa suplementar do Estado; o princípio da liberdade de empresa corrige-se com o da definição da função social da empresa; o princípio da liberdade de lucro, bem como o da liberdade de competição, moderam-se com o da repressão do abuso de poder econômico; o princípio da liberdade de contratação limita-se pela aplicação dos princípios de valorização do trabalho e da harmonia e solidariedade entre as categorias sociais de produção; $e$, finalmente, o princípio da propriedade privada restringe-se com o princípio da função social da propriedade." 14 (grifos no original)

Ora bem: se a liberdade para fixar preços de acordo com o mercado concorrencial é da própria essência da livre iniciativa, ela não pode ser eliminada de forma

um critério abstrato que imponha a supremacia de um sobre o outro, deve-se, à vista do caso concreto, fazer concessōes recíprocas, de modo a produzir-se um resultado socialmente desejável, sacrificando o mínimo de cada um dos princípios ou direitos fundamentais em oposição. O legislador não pode, arbitrariamente, escolher um dos interesses em jogo e anular o outro, sob pena de violar o texto constitucional. Relembre-se: as regras incidem sob a forma de 'tudo ou nada' (Dworkin), ao passo que os princípios precisam ser sopesados". Sobre a teoria dos princípios e a ponderação de valores, veja-se Ronald Dworkin, Taking rights seriously, 1977; Robert Alexy, Teoria de los derechos fundamentales, 1997, p. 83; Daniel Sarmento, A ponderação de interesses na Constituição Federal, 2000; e Heinrich Scholler, O princípio da proporcionalidade no direito constitucional e administrativo da Alemanha, Trad. Ingo Wolfgang Sarlet, 1999, Revista Interesse Público n², p. 93 e ss..

12 Sobre o assunto, v. também Luis Gustavo Grandinetti Castanho de Carvalho, Direito de informação e liberdade de expressão, 1999.

13 Celso Antonio Bandeira de Mello, Curso de direito administrativo, 11* ed., 1999, p. 490/1.

14 Diogo de Figueiredo Moreira Neto, Ordem económica e desenvolvimento na Constituição de 1988,1989 , p. 28. 
peremptória, sob pena de negação do princípio, e não de ponderação com outros valores. A menos que - e este é o ponto a que se chegará mais à frente - o controle prévio fosse necessário para recompor o próprio sistema de livre iniciativa.

Além desses dois princípios fundamentais - livre iniciativa e valorização do trabalho -, o art. 170 apresenta, ainda, um conjunto de princípios setoriais ${ }^{15}$ que, em harmonia com esses, deverão conduzir a ordem econômica. A eles se dedica o tópico seguinte.

\section{Princípios da ordem econômica}

Além de repetir que a valorização do trabalho humano e a livre iniciativa constituem os fundamentos da ordem econômica, como já o são do Estado de forma mais geral, o art. 170 da Constituição enuncia os demais princípios que devem orientar a atuação do Estado e dos particulares nos processos de produção, circulação, distribuição e consumo das riquezas do País. Confira-se a íntegra do dispositivo:

"Art. 170. A ordem econômica, fundada na valorização do trabalho humano e na livre iniciativa, tem por fim assegurar a todos existência digna, conforme os ditames da justiça social, observados os seguintes princípios:

I - soberania nacional;

II - propriedade privada;

III - função social da propriedade;

IV - livre concorrência;

$V$ - defesa do consumidor;

$V I$ - defesa do meio ambiente;

$V I I$ - redução das desigualdades regionais e sociais;

VIII - busca do pleno emprego;

IX - tratamento favorecido para as empresas de pequeno porte constituídas sob as leis brasileiras e que tenham sua sede e administração no País."

Da leitura dos princípios setoriais em questão, é fácil perceber que não há uma homogeneidade funcional entre eles. $O$ papel que a livre concorrência desempenha na ordem econômica é diverso daquele reservado ao princípio que propugna pela busca do pleno emprego ou pela redução das desigualdades regionais e sociais. A vista dessa constatação, é possível agrupar estes princípios em dois grandes grupos, conforme se trate de princípios de funcionamento da ordem econômica e de princípios-fins. Em linhas gerais, os princípios de funcionamento estabelecem os parâmetros de convivência básicos que os agentes da ordem econômica deverão observar. Os princípios fins, por sua vez, descrevem realidades materiais que o constituinte deseja sejam alcançadas. Convém analisar cada uma dessas categorias separadamente.

15 Sobre a distinção entre princípios fundamentais, gerais e setoriais, v. Luís Roberto Barroso, Interpretação e aplicação da constituição, 3' ed., 1999, p. 147 e ss.. 


\section{II.1. Principios de funcionamento}

Os princípios de funcionamento referem-se à dinâmica das relações produtivas, às quais todos os seus agentes estão vinculados. Podem ser classificados como princípios de funcionamento aqueles referidos nos incisos I a VI do artigo 170, a saber: (i) soberania nacional, (ii) propriedade privada, (iii) função social da propriedade, (iv) livre concorrência, (v) defesa do consumidor e (vi) defesa do meio ambiente.

\section{(i) Soberania nacional}

Soberania é um atributo essencial do Estado, sendo conceito de dupla significação: do ponto de vista do direito internacional, expressa a idéia de igualdade, de não subordinação; do ponto de vista interno traduz a supremacia da Constituição e da lei, e da superioridade jurídica do Poder Público na sua interpretação e aplicação. Se o Estado brasileiro decretar embargo comercial a um país, proibindo as exportações, todas as empresas terão de sujeitar-se. Se partes privadas escolherem contratualmente a aplicação de lei estrangeira em inatéria na qual a norma brasileira seja de aplicação cogente, é esta que prevalecerá. A própria reserva de mercado em setor estratégico é manifestação de soberania nacional na ordem econômica.

(ii) Propriedade privada e função social da propriedade

A propriedade privada é condição inerente à livre iniciativa e lugar da sua expansão ${ }^{16}$, além de direito individual constitucionalmente assegurado ${ }^{17}$. Sua função como princípio setorial da ordem econômica é, em primeiro lugar, assegurar a todos os agentes que nela atuam ou pretendam atuar a possibilidade de apropriação privada dos bens e meios de produção. Ao mesmo tempo, impõe aos indivíduos em geral o respeito à propriedade alheia e limita a ação do Estado, que só poderá restringir o direito à propriedade nas hipóteses autorizadas pela Constituição Federal ${ }^{18}$.

Nada obstante, e superando uma concepção puramente individualista da propriedade, o texto constitucional estabeleceu que, na ordem econômica por ele disciplinada, a propriedade deverá ter uma função social. O conceito é relativamente difuso, mas abriga idéias centrais como o aproveitamento racional, a utilização

16 Tércio Sampaio Ferraz Jr, Congelamento de preços - tabelamentos oficiais (parecer), Revista de Direito Público n 91, 1989, p. 77.

$17 \mathrm{CF}$, art. $5^{\circ}, \mathrm{XXII}$.

18 A Constituição enunciou quatro formas de intervenção estatal na propriedade privada, a saber: a) a instituição e cobrança de tributos, obedecidas as limitaçōes constitucionais ao poder de tributar (art. 148 e ss., especialmente o art.150), dentre as quais figura a proibição de utilizar tributo com efeito de confisco; b) privação de bens por meio de devido processo legal, assegurada a ampla defesa e o contraditório aos litigantes (art. $5^{\circ}$, LIV e LV); c) o perdimento de bens (art. $5^{\circ}$, XLVI, b) e a expropriação, sem indenização, dos bens envolvidos no cultivo de plantas psicotrópicas e no tráfico de entorpecentes (art. 243), como modalidade de pena criminal; e d) a desapropriação, garantida, como regra, prévia e justa indenização, e a requisição ou ocupação temporárias, assegurada igualmente a indenização se houver dano (arts. $5^{\circ}$, XXIV, $182, \S 4^{\circ}$, III, 184 e $5^{\circ}$, XXV). 
adequada dos recursos naturais, a preservação do meio ambiente, o bem-estar da comunidade $^{19}$. A frustração de tal mandamento constitucional dá ensejo a sanções previstas na própria Carta ${ }^{20}$.

(iii) Livre concorrência e defesa do consumidor

O princípio da livre concorrência, corolário direto da liberdade de iniciativa, expressa a opção pela economia de mercado. Nele se contém a crença de que a competição entre os agentes econômicos, de um lado, e a liberdade de escolha dos consumidores, de outro, produzirão os melhores resultados sociais: qualidade dos bens e serviços e preço justo. Daí decorre que o Poder Público não pode pretender substituir a regulação natural do mercado por sua ação cogente, salvo as situações de exceção que serão aqui tratadas. Por outro lado, os agentes privados têm não apenas direito subjetivo à livre concorrência, mas também o dever jurídico de não adotarem comportamentos anticoncorrenciais, sob pena de se sujeitarem à ação disciplinadora e punitiva do Estado.

Em suma: a opção por uma economia capitalista se funda na crença de que o método mais eficiente de assegurar a satisfação dos interesses do consumidor de uma forma geral é através de um mercado em condições de livre concorrência, especialmente no que diz respeito a preços.

A experiência demonstrou, todavia, que o sistema de auto-regulação do mercado nem sempre é eficaz em relação a um conjunto de outros aspectos dos produtos e serviços, como qualidade e segurança, veracidade das informações ao consumidor, vedação de cláusulas abusivas, atendimento pós-consumo etc. Daí a necessidade de uma regulamentação específica de proteção ao consumidor, que veio inscrita inclusive como um direito individual constitucionalizado ${ }^{21}$. Trata-se, aqui, tanto de um princípio de funcionamento da ordem econômica, ao qual está vinculada a iniciativa privada, quanto de um dever do Estado. A ele cabe, não apenas assegurar um mercado efetivamente concorrencial, como também criar condições eqüitativas entre partes naturalmente desiguais, ainda que de forma induzida, e assegurar condições objetivas de boa fé negocial ${ }^{22}$.

(iv) Defesa do meio ambiente

Por fim, a preservação do meio ambiente condiciona o exercício das atividades econômicas em geral. O constituinte de 1988 não apenas incluiu sua defesa entre os princípios da ordem econômica (CF, art. 170, VI), como também dedicou todo um

19 Miguel Reale Jr., Casos de direito constitucional, 1992, p. 14: “A propriedade exerce uma função social, se realiza um fim economicamente útil, produtivo e em benefício do proprietário e de terceiros, mormente os que com o trabalho intervêm no processo de utilização de meios econômicos.".

20 E.g., CF, arts. $182, \S 4$ e 184.

21 CF, art. $5^{\circ}$, XXXII: "o Estado promoverá, na forma da lei, a defesa do consumidor;".

22 Sobre o tema, v. Teresa Negreiros, Fundamentos para uma interpretação constitucional do princípio da boa fé, 1998. 
capítulo (Capítulo VI do Título VIII) à sua disciplina, elevando-o à categoria de direito de todos. Confira-se o teor do caput do art. 225 da Carta, in verbis:

"Art. 225. Todos têm direito ao meio-ambiente ecologicamente equilibrado, bem de uso comum do povo e essencial à sadia qualidade de vida, impondo-se ao Poder Público e à coletividade o dever de defendê-lo e preservá-lo, para as presentes e futuras gerações."

O agente econômico, público ou privado, não pode destruir o meio ambiente a pretexto de exercer seu direito constitucionalmente tutelado da livre iniciativa. Um ambiente saudável é o limite ao livre exercício da atividade econômica e, para defendê-lo e garantir a sadia qualidade de vida da população, o Estado tem o poder-dever de intervir na atuação empresarial, mediante a edição de leis e regulamentos que visem a promover o desenvolvimento sustentado ${ }^{23}$.

Este conjunto de princípios setoriais, acima examinados, forma, em suma, as "regras do jogo", que limitam e obrigam a conduta dos particulares. O destinatário principal dos princípios de funcionamento da ordem econômica é, como se vê, a iniciativa privada (e também o Estado quando atua empresarialmente, nos termos do art. 173 da Constituição ${ }^{24}$ ). Cabe ao Poder Público, nesse particular, regulamentar aquilo que lhe compete - como, e.g., os direitos do consumidor - e respeitar, sem outras interferências não autorizadas, o exercício da livre iniciativa.

\section{II.2. Princípios-fins}

Os princípios-fins delineiam os objetivos que, como produto final, a ordem econômica como um todo deverá atingir. Eles figuram tanto no caput do art. 170 quanto em seus incisos finais. São eles: (i) existência digna para todos; (ii) redução das desigualdades regionais e sociais, (iii) busca do pleno emprego; (iv) e a expansão das empresas de pequeno porte constituídas sob as leis brasileiras e que tenham sua sede e administração no país.

23 Maria Helena Diniz, Dicionário Jurídico, vol.2, 1998, p. 94. A autora define a já célebre expressão nos seguintes termos: “Desenvolvimento sustentado. Direito Internacional Público. Segundo a Comissão Mundial sobre Meio Ambiente e Desenvolvimento, é aquele que visa atender às necessidades do presente, sem que se comprometa a capacidade da futura geração de satisfazer as próprias necessidades". Observe-se que os deveres do Estado para com a preservação do meio-ambiente não se restringem à regulação das atividades econômicas.

$24 \mathrm{CF}$, art. 173: "Ressalvados os casos previstos nesta Constituição, a exploração direta de atividade econômica pelo Estado só será permitida quando necessária aos imperativos da segurança nacional ou a relevante interesse coletivo, conforme definidos em lei.". O $\S 1^{\circ}$, II, do mesmo artigo complementa: " $\$ 1^{\circ} \mathrm{A}$ lei estabelecerá o estatuto jurídico da empresa pública, da sociedade de economia mista e de suas subsidiárias que explorem atividade econômica de produção ou comercialização de bens ou de prestação de serviços, dispondo sobre: (...) II - a sujeição ao regime jurídico próprio das empresas privadas, inclusive quanto aos direitos e obrigações civis, comerciais, trabalhistas e tributários;". 
Cada um desses princípios descreve uma realidade fática desejada pelo constituinte e comandada ao Poder Público. Assim, o constituinte deseja o fortalecimento das empresas brasileiras de pequeno porte, admitindo, então, tratamento favorecido por parte do Estado. Além disso, a Constituição harmoniza os objetivos da ordem econômica - redução das desigualdades, pleno emprego e existência digna para todos - com os objetivos fundamentais da República Federativa do Brasil, constantes do art. $3^{\circ} \mathrm{da}$ Carta. Também ali pode-se ler, nos incisos III e IV, que erradicar a pobreza e a marginalização, reduzir as desigualdades sociais e regionais, e promover o bem de todos, sem preconceitos de origem, raça, sexo, cor, idade e quaisquer outras formas de discriminação, são objetivos fundamentais do Estado brasileiro como um todo ${ }^{25}$.

Assim, como a própria expressão sugere, os princípios-fins são finalidades a que visa o Estado na ordem econômica, já que, ao lado dos particulares, o Poder Público também é um agente econômico. Vale dizer, representam os objetivos sociais do Estado dentro dessa mesma ordem, informando a política econômica do Governo no sentido da plena realização dos preceitos constitucionais.

Uma última observação importante a ser feita a respeito dos princípios setoriais, em qualquer de suas categorias, é que nenhum deles - desde a meta de assegurar a todos existência digna, até o tratamento favorecido para as empresas nacionais de pequeno porte - poderá contrariar ou esvaziar os princípios fundamentais da ordem econômica, tal como positivados no caput do art. 170, ainda que lhes estabeleçam certo nível de restrições. Não se pode, sob o pretexto de realizar qualquer deles, eliminar a livre iniciativa ou depreciar o trabalho humano. Confira-se, sobre o ponto, Celso Antonio Bandeira de Mello, in verbis:

"Seria um verdadeiro absurdo, um contra-senso cabal, extrair do parágrafo de um artigo a outorga de poder para nulificar o que se contém em sua cabeça e em um de seus incisos; o disparate interpretativo seria particularmente inadmissivel quando se sabe que o artigo e o inciso em questão (170 e seu inciso IV) apresentam-se, e de modo declarado, como sendo respectivamente, um dos 'fundamentos da ordem econômica' $e$ um dos 'princípios' retores dela. Um fundamento constitucional que pudesse ser arredado por obra de legislação ordinária ou um princípio que esta pudesse menoscabar, a toda evidência, nada valeriam e o constituinte seria um rematado tolo se houvesse pretendido construi-los com tal fragilidade." 26

A conclusão a que se chega, portanto, é que nenhum desses princípios setoriais poderá restringir a livre iniciativa a ponto de afetar seus elementos essenciais. Sendo

$25 \mathrm{CF}$, art. $3^{\circ}$, III e IV: “Constituem objetivos fundamentais da República Federativa do Brasil (...) III - erradicar a pobreza e a marginalização e reduzir as desigualdades sociais e regionais; IV promover o bem de todos, sem preconceitos de origem, raça, sexo, cor, idade e quaisquer outras formas de discriminação.".

26 Celso Antonio Bandeira de Mello, Curso de direito administrativo, $11^{\star}$ ed., 1999, p. 490-1. 
a livre fixação de preços um desses elementos, não se poderá excepcioná-la apenas com fundamento em qualquer desses princípios, pois isso representaria uma violação do fundamento da própria ordem econômica.

\section{Agentes da ordem econômica}

\section{III.1. Papel do Estado na ordem econômica}

Preservação e promoção dos princípios de funcionamento e implementação de programas para a realização dos princípios-fins

Em linha de coerência com a classificação acima delineada - princípios de funcionamento e princípios-fins - , varia o papel do Estado na implementação de cada um deles. Os princípios de funcionamento, relembre-se, são endereçados primordialmente à atividade do setor privado. Os princípios-fins determinam a política econômica estatal. Veja-se, brevemente, o conteúdo e os limites da atuação estatal na realização de cada um deles.

Cabe ao Estado fiscalizar o regular atendimento, pela iniciativa privada, dos princípios de funcionamento da ordem econômica. No desempenho dessa competência, deverá editar normas coibindo abusos contra o consumidor, prevenindo danos à natureza ou sancionando condutas anti-concorrenciais, para citar alguns exemplos. Ao traçar esta disciplina, deverá o Poder Público, como natural, pautar-se no quadro da Constituição, tendo como vetor interpretativo os fundamentos do Estado e da ordem econômica: livre iniciativa e valorização do trabalho.

É certo que alguns dos princípios setoriais podem autorizar a produção de normas que interfiram com a livre-iniciativa. Isto é natural e inevitável. Mas tais princípios não têm força jurídica para validar atos que venham suprimir a livre iniciativa ou vulnerá-la no seu núcleo essencial. Tércio Sampaio Ferraz Jr., em estudo sobre o tema, sintetizou o papel do Estado na preservação e promoção dos princípios de funcionamento da ordem econômica, verbis:

"Em conseqüência, deve-se dizer, portanto, que o sentido do papel do Estado como agente normativo e regulador está delimitado, negativamente, pela livre iniciativa, que não pode ser suprimida. $O$ Estado, ao agir, tem o dever de omitir a sua supressão. Positivamente, os limites das funções de fiscalização, estímulo e planejamento estão nos princípios da ordem, que são a sua condição de possibilidade. O primeiro deles é a soberania nacional. Nada fora do pacto constituinte. Nenhuma vontade pode se impor de fora do pacto constitucional, nem mesmo em nome de alguma racionalidade da eficiência, externa e tirânica. O segundo é a propriedade privada, condição inerente à livre iniciativa. O terceiro é a função social da propriedade, que tem a ver com a valorização do trabalho humano e confere o conteúdo positivo da liberdade de iniciativa. $O$ quarto é a livre concorrência: a livre iniciativa é para todos, sem exclusões e discriminações. O quinto é a defesa do consumidor, devendo-se velar para que a produção esteja a serviço do 
consumo, e não este a serviço daquela. O sexto é a defesa do meio ambiente, entendendo-se que uma natureza sadia é um limite à atividade e também sua condição de exercício. (...)

Esses nove princípios não se contrapõem aos fundamentos da ordem, mas dão-lhes seu espaço relativo. Cumpre ao Estado assegurar os fundamentos, a partir dos princípios. Não se pode, por isso, em nome de qualquer deles eliminar a livre iniciativa nem desvalorizar o trabalho humano. Fiscalizar, estimular, planejar, portanto, são funçōes a serviço dos fundamentos da ordem, conforme seus princípios. Jamais devem ser entendidos como funções que, supostamente em nome dos principios, destruam seus fundamentos." (negrito acrescentado) ${ }^{27}$

Cabe ao Estado, do mesmo modo, a responsabilidade de implementação dos princípios-fins contidos no art. 170 , sempre visando a assegurar a todos existência digna, conforme os ditames da justiça social. No desempenho de tal atribuição, compete-lhe, por exemplo, levar a efeito programas que promovam a redução da desigualdade ou que visem ao pleno emprego. Ao mesmo tempo, é dever do Estado, como agente da ordem econômica, criar mecanismos de incentivo que estimulem a iniciativa privada a auxiliar na consecução desses mesmos fins.

Nessa linha de raciocínio, é próprio do papel do Estado procurar influir legitimamente nas condutas dos agentes econômicos, através de mecanismos de fomento — incentivos fiscais, financiamentos públicos, redução da alíquota de impostos -, sem que possa, todavia, obrigar a iniciativa privada à adesão. De fato, nos termos do art. 174 da Carta em vigor, o Estado exercerá funções de incentivo e planejamento, 'sendo este determinante para o setor público e indicativo para o setor privado'. Sobre o tema, vejam-se as manifestações precisas de Celso Antônio Bandeira de Mello e Marcos Juruena Villela Souto, respectivamente:

“... com o advento da Constituição de 1988, tornou-se enfaticamente explícito que nem mesmo o planejamento econômico - feito pelo Poder Público para algum setor de atividade ou para o conjunto deles - pode impor-se como obrigatório para o setor privado. É o que está estampado com todas as letras, no art. 174. (...)

Em suma: a diç̧ão categórica do artigo deixa explícito que, a título de planejar, o Estado não pode impor aos particulares nem mesmo o atendimento às diretrizes ou intençōes pretendidas, mas apenas incentivar, atrair os particulares, mediante planejamento indicativo que se apresente como sedutor para condicionar a atuação da iniciativa privada." (negrito acrescentado) ${ }^{28}$

27 Tércio Sampaio Ferraz Jr., Congelamento de preços - tabelamentos oficiais (parecer), in Revista de Direito Público n 91, 1989, p. $77 / 78$.

28 Celso Antônio Bandeira de Mello, Liberdade de iniciativa. Intromissão estatal indevida no domínio econômico, 1999, in Revista de Direito Administrativo e Constitucional $n^{\circ} 1$, p. 178/179. 
"Se o planejamento é determinante para o setor público, por força do princípio da livre iniciativa, é apenas indicativo para o setor privado; quer dizer, o planejamento da economia não obriga a empresa privada a atuar em áreas consideradas estratégicas, mas apenas a incentiva (sanções positivas) a colaborar com o desenvolvimento que vai proporcionar o bem-estar geral (surgem benefícios fiscais, subsídios, empréstimos facilitados etc.)" 29

Em outras palavras, não se pode, sem prejuízo dos princípios fundamentais da ordem econômica, consagrados na Lei Maior, transferir aos particulares de forma cogente o ônus de concretizar princípios-fins de responsabilidade do Estado. A realização de seus próprios objetivos privados não é incompatível - deve-se enfatizar - com a função social da empresa e certos deveres de solidariedade, mas não inclui o de substituir-se ao Poder Público. Como é intuitivo, o papel da iniciativa privada na ordem econômica é diverso daquele desempenhado pelo Estado. $O$ tema é desenvolvido a seguir.

\section{III.2. Papel da iniciativa privada na ordem econômica}

De acordo com o sistema constitucional que aqui se vem expondo, é fora de dúvida que os particulares são os principais atores da ordem econômica brasileira. Têm eles direito subjetivo à livre concorrência e à busca do lucro e o dever jurídico de observarem os princípios de funcionamento da atividade econômica. $O$ significado dessa preeminência da livre iniciativa foi captado e enfatizado por Tércio Sampaio Ferraz Jr., nos seguintes termos:

"Afirmar a livre iniciativa como base é reconhecer na liberdade um dos fatores estruturais da ordem, é afirmar a autonomia empreendedora do homem na conformação da atividade econômica, aceitando sua intrínseca contingência e fragilidade; é preferir, assim, uma ordem aberta ao fracasso a uma 'estabilidade' supostamente certa e eficiente. Afirma-se, pois, que a estrutura da ordem está centrada na atividade das pessoas e dos grupos e não na atividade do Estado. Isto não significa, porém, uma ordem do 'laissez faire', posto que a livre iniciativa se conjuga com a valorização do trabalho humano." 30

Tais idéias, naturalmente, não são incompatíveis com o conceito moderno de função social da empresa. Embora não referido de modo expresso no texto constitucional, integra ele o sistema jurídico, como decorrência da idéia de Estado demo-

29 Marcos Juruena Villela Souto, Constituição econômica, 1993, in Caderno de Direito Tributário $n^{\circ} 4$, p. 232.

30 Tércio Sampaio Ferraz Jr., Congelamento de preços - tabelamentos oficiais (parecer), in Revista de Direito Público n 91, 1989, p. 77. 
crático de direito, inspirada por valores como justiça social e participação. A empresa há de ter compromisso social com os parceiros com os quais interage e com a sociedade como um todo.

Tem, assim, deveres para com seus empregados e com a valorização social do trabalho, na forma da lei, bem como com a oferta de emprego e, em última análise, com a existência digna para todos. De parte isto, tem obrigações para com seus fornecedores, que asseguram o ciclo produtivo, e com os consumidores ${ }^{31}$, a quem se destina a atividade econômica e cujos direitos limitam seu exercício. Há também os vizinhos e a comunidade como um todo, titulares, em última análise, do direito ao meio ambiente saudável ${ }^{32}$ e beneficiários indiretos da utilização produtiva da propriedade $^{33}$.

Há, por fim, a responsabilidade social mais geral, consistente na contribuição tributária regular - cujos recursos sustentam a própria existência do Estado e permitem a prestação dos serviços públicos, a entrega de utilidades sociais e as políticas públicas voltadas à realização dos fins estatais.

Como se pode singelamente constatar, o regular exercício de suas atividades pelas empresas privadas - como tal entendido o que observa os princípios de funcionamento da ordem econômica - já viabiliza uma parte importante do bemestar social. $\mathrm{O}$ que o Estado não pode pretender, sob pena de subverter os papéis, é que a empresa privada, em i:gar de buscar o lucro, oriente sua atividade para a consecução dos princípios-fins da ordem econômica como um todo, com sacrifício da livre-iniciativa. Isto seria dirigismo, uma op̧̧ão por um modelo historicamente superado. $O$ Poder Público não pode supor, e.g., que uma empresa esteja obrigada a admitir um número $x$ de empregados, independentemente de suas necessidades, apenas para promover o pleno emprego. Ou ainda que o setor privado deva compulsoriamente doar produtos para aqueles que não têm condições de adquiri-los, ou que se instalem fábricas obrigatoriamente em determinadas regiões do País, de modo a impulsionar seu desenvolvimento.

Ao Estado, e não à iniciativa privada, cabe desenvolver ou estimular práticas redistributivistas ou assistencialistas. É do Poder Público a responsabilidade primária. Poderá desincumbir-se dela por iniciativa própria ou estimulando comportamentos da iniciativa privada que conduzam a esses resultados, oferecendo vantagens fiscais, financiamentos, melhores condições de exercício de determinadas atividades, dentre outras formas de fomento.

IV. Intervenção estatal na ordem econômica: disciplina.

\section{IV.1. Modalidades de intervenção estatal na ordem econômica}

Identificados os papéis do Estado na ordem econômica, é possível agora classificar suas modalidades de intervenção e associá-las a cada um deles. A sistemati- 
zação doutrinária das formas de intervenção do Estado na economia varia conforme o critério adotado. Há autores que se referem à intervenção $(a)$ regulatória, $(b)$ concorrencial, (c) monopolista e $(d)$ sancionatória ${ }^{34}$. Outros classificam-na em (a) poder de polícia, $(b)$ incentivos à iniciativa privada e $(c)$ atuação empresarial ${ }^{35}$. Nessa linha, é possível identificar três mecanismos de intervenção estatal no domínio econômico: a atuação direta, o fomento e a disciplina.

O Estado pode interferir na ordem econômica mediante uma atuação direta, isto é: assumindo, ele próprio, o papel de produtor ou prestador de bens ou serviços. Essa modalidade de intervenção assume duas apresentações distintas: (a) a prestação de serviços públicos e (b) a exploração de atividades econômicas. Entretanto, cabe não perder de vista que a atuação direta do Estado na economia é excepcional, só autorizada nos termos constitucionais, por representar uma exclusão da livre iniciativa.

Este caráter excepcional é enfatizado pela Constituição em duas normas, uma implícita e outra explícita. A primeira limita a criação de novos monopólios públicos, além daqueles que já constam da $\mathrm{Carta}^{36}$. E a segunda impõe a necessidade de lei autorizativa de qualquer forma de exploração direta de atividade econômica pelo Estado, cujos pressupostos são os imperativos da segurança nacional ou relevante interesse coletivo. Além disso, a Constituição estabelece que, nessas hipóteses, o Estado-empresário estará submetido às mesmas condições que os particulares, de modo a evitar a concorrência desleal, com prejuízo maior para o princípio da livre iniciativa ${ }^{37}$.

34 Diogo de Figueiredo Moreira Neto, Curso de direito administrativo, 1996, p. 365.

35 Celso Antonio Bandeira de Mello, Curso de direito administrativo, 1996, p. 434-5.

36 Essa é a posição consolidada da doutrina. Veja-se, por todos, Fábio Konder Comparato, Monopólio público e domínio público in Direito Público: estudos e pareceres, 1996, p. 149: “A vigente Carta Constitucional preferiu seguir o critério de enumeração taxativa dos setores ou atividades em que existe (independentemente, pois, de criação por lei) monopólio estatal, deferido agora exclusivamente à União (art. 177 e 21, X, XI e XII). Quer isto dizer que, no regime da Constituição de 1988, a lei já não pode criar outros monopólios, não previstos expressamente no texto constitucional, pois contra isso opõe-se o princípio da livre iniciativa, sobre o qual se funda toda a ordem econômica (art. 170)." e Celso Antônio Bandeira de Mello, Curso de direito administrativo, 1996, p. 441: "Finalmente, convém lembrar que a Constituição previu o monopólio de certas atividades. São elas unicamente as seguintes, consoante arrolamento do art. 177 da Constituição (...) Tais atividades monopolizadas não se confundem com serviços públicos. Constituem-se, também elas, em 'serviços governamentais', sujeitos, pois, às regras do Direito Privado. Correspondem, pura e simplesmente, a atividades econômicas subtraídas do âmbito da livre iniciativa.".

$37 \mathrm{CF}$, art. 173, § 10: "A lei estabelecerá o estatuto jurídico da empresa pública, da sociedade de economia mista e de suas subsidiárias que explorem atividade econômica de produção ou comercialização de bens ou de prestação de serviços, dispondo sobre:

(...)

II - a sujeição ao regime jurídico próprio das empresas privadas, inclusive quanto aos direitos e obrigações civil, comerciais, trabalhistas e tributários;

(...)

$\S 2^{\circ}$ As empresas públicas e as sociedades de economia mista não poderão gozar de privilégios fiscais nāo extensivos às do setor privado.". 
De outra parte, o Estado interfere no domínio econômico por via do fomento, isto é, apoiando a iniciativa privada e estimulando (ou desestimulando) determinados comportamentos, por meio, por exemplo, de incentivos fiscais ou financiamentos públicos. ${ }^{38}$ Esta é a modalidade própria de que se utiliza o Estado para atingir os princípios-fins da ordem econômica. Como registram Diogo de Figueiredo Moreira Neto e Ney Prado:

\begin{abstract}
"Através do fomento público, o Estado deverá desenvolver uma atuação suasória, não cogente, destinada a estimular as iniciativas privadas que concorram para restabelecer a igualdade de oportunidades econômicas e sociais ou suprir deficiências da livre empresa no atendimento de certos aspectos de maior interesse coletivo." ${ }^{39}$.
\end{abstract}

A peculiaridade dessa forma de intervenção estatal é que ela opera por meio de normas diretivas. A adesão ao comportamento sugerido constitui mera opção dos agentes econômicos que se beneficiariam com os mecanismos de fomento criados em lei. Esse aspecto é sublinhado por Eros Roberto Grau, litteris:

"No caso das normas de intervenção por indução defrontamo-nos com preceitos que, embora prescritivos (deônticos), não são dotados da mesma carga de cogência que afeta as normas de intervenção por direção. Trata-se de normas dispositivas. Não, contudo, no sentido de suprir a vontade do seu destinatário, porém, na dicção de Modesto Carvalhosa, no de 'levá-lo a uma opção econômica de interesse coletivo e social que transcende os limites do querer individual'. Nelas, a sanção, tradicionalmente manifestada como comando, é substituída pelo expediente do convite (...). Ao destinatário da norma resta aberta a alternativa de não se deixar por ela seduzir, deixando de aderir à prescrição nela vinculada. Se adesão a ela manifestar, no entanto, resultará juridicamente vinculado por prescrições que correspondem aos benefícios usufruídos em decorrência dessa adesão. Penetramos, aí, o universo do direito premial." 40

Por fim, o Poder Público interfere com a atividade econômica traçando-lhe a disciplina. $\mathrm{O}$ propósito principal dessa forma de intervenção, como já se viu, é a

38 Luiz Carlos Bresser Pereira, Cidadania e res publica: a emergência dos direitos republicanos, in Revista de Direito Administrativo ${ }^{\circ} 208$, p. 147 e ss.. Em interessante estudo, o autor identifica como direito republicano o direito a que os recursos públicos sejam aplicados no interesse e benefício de toda a coletividade, e não de alguns grupos privados. Embora nem sempre se concorde com os exemplos utilizados pelo autor (que, por vezes, não distingue entre direitos legitimamente adquiridos e interesses privados ilegítimos), o trabalho merece registro.

39 Diogo de Figueiredo Moreira Neto e Ney Prado, Uma análise sistêmica do conceito de ordem econômica e social, 1987, in Revista de Informação Legislativa do Senado Federal n ${ }^{\circ}$ 96/121, p. 132.

40 Eros Roberto Grau, A ordem econômica na Constituição de 1988, 1990, p. 164. 
preservação e promoção dos princípios de funcionamento da ordem econômica. Esta modalidade de intervenção na ordem econômica será objeto de análise mais detalhada nos itens seguintes.

\section{IV.2. Limites e fundamentos legítimos da intervenção disciplinadora}

A modalidade de intervenção estatal mais importante para os fins deste estudo, como já se registrou, é a disciplina. Aqui, o Poder Público atua como agente normativo e regulador, exercendo a função de fiscalização, prevista no já referido art. 174 da Carta de $1988^{41}$, e é no âmbito da disciplina estatal da atividade econômica que se insere a discussão acerca do controle de preços.

O Estado disciplina a atividade econômica mediante a edição de leis, de regulamentos e pelo exercício do poder de polícia. De fato, o Poder Público exerce competências normativas primárias e edita normas decisivas para o desempenho da atividade econômica, algumas com matriz constitucional, como, por exemplo, o Código do Consumidor (art. 5, XXXII), a lei de remessa de lucros (art. 172), a lei de repressão ao abuso do poder econômico (art. 173, § 4), dentre inúmeras outras. Exerce, ademais, competências normativas de cunho administrativo, editando decretos regulamentares, resoluções, deliberações, portarias, algumas em domínios relevantíssimos como a política de crédito e a política de câmbio, em meio a muitas outras. Por fim, desempenha, também, o poder de polícia, restringindo direitos e condicionando o exercício de atividades em favor do interesse coletivo (e.g., polícia ambiental, sanitária, fiscalização trabalhista).

Diferentemente do que se passa com os instrumentos de fomento, a disciplina impõe comportamentos compulsórios, mediante a edição de normas cogentes, cuja violação sujeita o infrator a uma sanção. Na medida em que determinadas condutas são consideradas obrigatórias, opera-se uma retração lógica do espaço da liberdade de iniciativa, que, como visto, não é um princípio absoluto. Porém, ensina a experiência, pode ocorrer que, com a intenção ou a pretexto de restringir e fiscalizar, se chegue a aniquilar e esvaziar a livre iniciativa. Daí a importância de se delinear o regime jurídico da própria disciplina, à luz da Constituição.

Do exame sistemático do texto constitucional, é possível identificar ao menos 2 (duas) ordens de limitações à intervenção disciplinadora do Estado sobre a ordem econômica e 3 (três) conjuntos de fundamentos válidos que podem desencadear essa intervenção. Os limites correspondem aos princípios da livre iniciativa (e, no seu âmbito, especialmente a livre concorrência) e da razoabilidade. Os fundamentos válidos para a disciplina consistem: (i) na reorganização da própria livre iniciativa e livre concorrência, nas hipóteses excepcionais em que o mercado privado haja se desorganizado; (ii) na valorização do trabalho humano; e (iii) nos princípios de

$41 \mathrm{CF}$, art. 174: "Como agente normativo e regulador da atividade econômica, o Estado exercerá, na forma da lei, as funções de fiscalização, incentivo e planejamento, sendo este determinante para o setor público e indicativo para o setor privado.". 
funcionamento da ordem econômica. Veja-se cada um desses elementos separadamente.

\section{a) Limites da disciplina}

(i) Elementos fundamentais da livre iniciativa e livre concorrência e (ii) princípio da razoabilidade

A atuação do Estado, como agente normativo e regulador do fenômeno econômico comporta uma gradação importante, à vista do projeto ideológico escolhido. Historicamente, têm sido experimentados modelos que vão de um extremo a outro: do controle absoluto ao liberalismo radical (laissez-faire), passando por formas intermediárias. A intensidade do poder de intervenção do Estado leva à distinção entre os conceitos de dirigismo e disciplina.

O dirigismo econômico é próprio dos modelos coletivistas, baseados na planificação centralizada e cogente e na propriedade coletiva dos meios de produção. $O$ mercado deixa de estar centrado na atividade das pessoas e dos grupos privados e passa a ser largamente manipulado pelo Estado. Já nos Estados que optaram pela livre iniciativa, a disciplina é um instrumento de intervencionismo econômico prática que teve o seu ponto alto no período em que se fortaleceu a idéia de Estado de bem-estar social -, mas se rege por um postulado essencial: o de que o livre mercado concorrencial é o mecanismo mais eficaz de produção de riquezas e bem estar (ainda que longe de ser perfeito). Em suma: a disciplina é forma de intervenção que se dá não contra o mercado, mas a seu favor ${ }^{42}$.

À luz da Constituição brasileira, a ordem econômica funda-se, essencialmente, na atuação espontânea do mercado. O Estado pode, evidentemente, intervir para implementar políticas públicas, corrigir distorções e, sobretudo, para assegurar a própria livre iniciativa e promover seu aprimoramento. Este é o fundamento e o limite de sua intervenção legítima. A característica da disciplina está, exatamente, em que ela não pretende nem pode pretender substituir o mercado em seu papel central do sistema econômico.

Ora bem: o controle prévio de preços não é um dos instrumentos próprios da disciplina, tal como pautada pela Constituição. É meio de atuação do dirigismo, que autoriza o total domínio da economia pelo Poder Público. Na síntese de Tércio Sampaio Ferraz Jr.:

“... aqui entra a distinção entre intervencionismo e dirigismo. O primeiro é atitude flexível, que visa a estimular o mercado e a definir as regras do

42 Tércio Sampaio Ferraz Júnior, Congelamento de Preços - Tabelamentos Oficiais, in Revista de Direito Público n 91, 1989, p. 76/86: “Distinto do intervencionismo é, nesse sentido, o dirigismo econômico, próprio das economias de planificação compulsória, e que pressupõe a propriedade estatal dos meios de produção, a coletivização das culturas agropecúrias e o papel do Estado como agente centralizador das decisōes econômicas de formação de preços e fixação de objetivos." 
jogo. Já o segundo se caracteriza por uma atitude rígida, que impõe autoritariamente certos comportamentos. Neste há uma direção central da economia que funciona na base de um plano geral obrigatório que todos executam; a entidade autora do plano determina a necessidade dos sujeitos $e$ a sua prioridade, fixa os níveis de produção e de preços e opera direta ou indiretamente a distribuição dos bens produzidos." 43

Adotar, portanto, uma política que altere a livre fixação dos preços pelas forças do mercado - sem que se esteja diante de uma deterioração tal do mercado em que esta seja a única medida capaz de restabelecer a livre iniciativa e a livre concorrência - importa, em última instância, a deturpação do modelo instituído pela Constituição de 1988. Em outras palavras: em condições regulares de funcionamento do mercado concorrencial, não é possível a intervenção estatal que elimine a livre iniciativa e a livre concorrência - de que é exemplo a supressão da liberdade de fixação dos preços -, seja qual for o fundamento adotado para a medida.

Além de observar o limite material representado pela livre iniciativa - livre concorrência, qualquer medida de disciplina do mercado, ainda que disponha de um fundamento legítimo, deverá apresentar-se de acordo com o princípio da razoabilidade. O princípio da razoabilidade é um mecanismo para controlar a discricionariedade legislativa e administrativa. Ele permite ao Judiciário invalidar atos legislativos ou administrativos quando: (a) não haja adequação entre o fim perseguido e o meio empregado; (b) a medida não seja exigível ou necessária, havendo caminho alternativo para chegar ao mesmo resultado com menor ônus a um direito individual; (c) não haja proporcionalidade em sentido estrito, ou seja, o que se perde com a medida tem maior relevo do que aquilo que se ganha.

Desse modo, em primeiro lugar, é preciso que haja um nexo racional e razoável entre a medida disciplinadora implementada e o objetivo que se pretende alcançar, tendo em vista o pressuposto fático que fundamenta a norma. Com efeito, a regra que vier a interferir no mercado deve ser apta a realizar e/ou restaurar o fim constitucional que autorizou sua edição. Vale dizer, deve haver uma correlação lógico-racional entre a distorção que se quer corrigir e o seu remédio.

O princípio da razoabilidade exige também, em segundo lugar, que, dentre as medidas aptas a atingir o resultado pretendido, seja escolhida aquela que produz a menor restrição aos direitos consagrados na Constituição. É preciso assegurar a presença do binômio necessidade/utilidade no caso concreto, com a conseqüente vedação do excesso. Por fim, a medida deverá ser comparativamente menos danosa aos princípios constitucionais que regem a ordem econômica que o próprio motivo da intervenção. Em outras palavras: o custo-benefício deverá ser positivo.

\section{b) Fundamentos da disciplina}

(i) Reorganização da livre iniciativa - livre concorrência, (ii) valorização

43 Tércio Sampaio Ferraz Jr., Congelamento de Preços - Tabelamentos Oficiais, in Revista de Direito Público n 91, 1989, p.83. 
do trabalho humano e (iii) realização dos princípios de funcionamento da ordem econômica.

Além de observar os limites constitucionais acima referidos, a ação disciplinadora do Estado se legitima na medida em que procure realizar determinados princípios constitucionais. A primeira possibilidade que justifica a intervenção disciplinadora do Estado, ainda que se trate de hipótese excepcional, é um quadro de deterioração generalizada do princípio da livre iniciativa e da livre concorrência, exigindo-se a ação estatal para sua reorganização. Este fundamento será examinado mais detalhadamente adiante, pois é o único que justifica medidas extremas que afetem a própria essência da livre iniciativa e da livre concorrência.

Em segundo lugar, a valorização do trabalho humano, por ser co-fundamento da ordem econômica brasileira, ao lado da livre iniciativa (CF, art. 170), pode justificar a intervenção estatal. De fato, embora o trabalho humano e a livre iniciativa possam identificar-se e potencializar-se mutuamente, é comum, em uma sociedade capitalista, que estejam em relação de tensão. Daí a legitimidade da atuação disciplinadora do Estado, impondo um elenco de direitos a serem preservados e a distribuição de parte dos proveitos obtidos com o esforço coletivo. É certo, todavia, que este fundamento jamais poderia legitimar o controle de preços: ainda que não houvesse a limitação material representada pelo núcleo do conceito de livre iniciativa, não haveria qualquer relação lógica entre controle de preços e valorização do trabalho.

Por fim, o terceiro fundamento da disciplina, e seu propósito principal, é, exatamente, preservar ou promover os princípios de funcionamento da ordem econômica. Justifica-se a disciplina estatal, em tese, na medida em que ela busque: (i) assegurar a soberania estatal e os próprios comandos constitucionais sobre a matéria; (ii) proteger a propriedade privada e assegurar a realização de sua função social; (iii) defender o consumidor; e (iv) defender o meio ambiente. Em todo caso, lembre-se, os limites constitucionais referidos acima deverão ser observados. Isto é: o Poder Público não poderá, ainda que com o propósito de promover esses princípios, violar o conteúdo básico da livre iniciativa e nem implementar qualquer medida que não resista ao teste da razoabilidade.

Não lhe cabe, assim, determinar o que produzir, onde comercializar, que preços praticar. A normatização que poderá a autoridade pública efetuar sobre a atividade econômica circunscreve-se, na lição de Celso Antônio Bandeira de Mello, à "compatibilização dos empreendimentos econômicos com exigências conaturais à segurança, à salubridade, à higidez do meio ambiente, à qualidade mínima do produto em defesa do consumidor e outros bens jurídicos que compõem a constelação de interesses coletivos." E complementa:

"É que o Estado em regime de livre iniciativa e livre concorrência consagrados na Constituição do País - não pode interferir na atividade econômica em si mesma, desempenhada por particulares. Em sendo elá 
legítima, vale dizer, não proscrita por lei, falece ao Poder Público a possibilidade de determinar a quantidade do produzido, ou de fixar o montante do produto a ser comercializado de cada vez e, como é de clareza solar, de quantificar as unidades que deverão ou poderão existir em cada embalagem." 44

\section{Parte II \\ LIMITES CONSTITUCIONAIS À DISCIPLINA DE PREÇOS POR PARTE DO ESTADO}

\section{Competência estatal em matéria de preços privados}

\section{V.1. A livre fixação de preços é elemento fundamental da livre iniciativa. $O$ controle prévio de preços como política pública regular viola princípio constitucional.}

Nos capítulos precedentes, cuidou-se genericamente da intervenção estatal, na modalidade de disciplina da ordem econômica. Cumpre agora aplicar as idéias desenvolvidas à questão específica do controle de preços. Deve-se assinalar, de plano, que o controle prévio de preços é medida própria de dirigismo econômico, e não meio legítimo de disciplina do mercado. A livre fixação de preços integra o conteúdo essencial da livre iniciativa e não pode ser validamente vulnerada, salvo situações extremas que envolvam o próprio colapso no funcionamento do mercado.

Diante de tal premissa, é possível assentar que, em situação de normalidade, independentemente dos fundamentos em tese admissíveis para a intervenção disciplinadora, o controle prévio ou a fixação de preços privados pelo Estado configura inconstitucionalidade patente. A Constituição brasileira não admite como política pública regular o controle prévio de preços.

Note-se que a situação de normalidade a que se fez referência não exclui, por natural, a possibilidade episódica da prática de ilícitos contra a ordem econômica. Diante de algum indício de conduta infratora ou anticoncorrencial, podem ser deflagrados os mecanismos próprios de apuração, mediante devido processo legal, e, se for o caso, de punição. Em situações normais, o controle estatal em matéria de preços de produtos e serviços será sempre posterior à verificação de práticas abusivas ou anticoncorrenciais, assegurados os direitos fundamentais à ampla defesa e ao devido processo legal (CF, art. $5^{\circ}$, LIV).

44 Celso Antônio Bandeira de Mello, Liberdade de iniciativa. Intromissão estatal indevida no domínio econômico, in A \& C - Revista de Direito Administrativo e Constitucional ${ }^{\circ} 01,1999$, pp. 179 e 174. 
V.2. Somente em situação de anormalidade do mercado, ausentes as condições regulares de livre concorrência, o princípio da livre iniciativa poderá sofrer ponderação para admitir o controle prévio de preços, observados determinados pressupostos

Admite-se, todavia, que em situações anormais seja possível o controle prévio de preços pelo Estado, na medida em que o mercado privado como um todo tenha se deteriorado a ponto de não mais operarem a livre iniciativa e a livre concorrência de forma regular. Nesses casos - excepcionais, repita-se - a intervenção se justifica, afastando o limite material acima referido, exatamente para reconstruir a prática de tais princípios. Isto é: para reordenar o mercado concorrencial de modo que a livre iniciativa e seus corolários possam efetivamente funcionar.

Note-se, porém, que o controle prévio de preços só é admissível por esse fundamento. E, mesmo assim, observado o princípio da razoabilidade. Os demais, representados pela valorização do trabalho humano e pelos princípios de funcionamento da ordem econômica, não podem justificar o controle prévio de preços, pois isso seria incompatível com o conteúdo básico da livre iniciativa. Esta proposição é válida, inclusive, em relação à atuação voltada para a proteção do consumidor que é um dos princípios de funcionamento da atividade econômica ${ }^{45}$. E, ademais, também quanto a este ponto, ocorreria o limite imposto pela razoabilidade, haja vista que existem mecanismos menos gravosos para esta proteção - incentivo à concorrência, punição administrativa, civil e penal dos infratores.

\section{V.3. Pressupostos constitucionais para o controle prévio de preços}

A admissão de que algum tipo de controle de preços pode ser legítimo - tese aqui defendida, em oposição a boa parte da doutrina — impõe, como contrapartida, a exigência de rígida observância dos condicionamentos constitucionais para sua adoção.

Com efeito, pelo princípio da unidade da Constituição, inexiste hierarquia entre as normas constitucionais, de forma que jamais se deve interpretar uma delas invalidando ou paralisando a eficácia de outra. Por assim ser, como já se teve ocasião de registrar, deve-se sempre preservar um núcleo mínimo dos princípios constitucionais em ponderação, sob pena de violar-se a unidade da Carta. Nesse sentido, há razoável consenso em que, mesmo quando admitido o controle de preços, ele sofre três limitações insuperáveis: a) deverá observar o princípio da razoabilidade; b) como medida excepcional, pressupõe uma situação de anormalidade e deve ser limitado no tempo; e c) em nenhuma hipótese pode impor a venda de bens ou serviços por preço inferior ao preço de custo, acrescido de um retorno mínimo, compatível com as necessidades de reinvestimento e de lucratividade proprias do setor privado.

45 E evidente que ao reorganizar o mercado e restabelecer o funcionamento regular da livre iniciativa e da livre concorrência, o controle de preços - quando admissível - estará funcionando como instrumento mediato de defesa do consumidor. Isso porque, como já referido, condições de concorrência reais constituem o principal mecanismo de proteção do consumidor no sistema constitucional brasileiro, especialmente no que diz respeito a preços. 
Não é o caso de se voltar a enunciar o conceito de razoabilidade e de seus sub-princípios. Mas algumas considerações podem ainda ser elucidativas. É que tem amplo curso na teoria econômica e entre seus tradutores jurídicos a tese de que a interferência estatal no preço de bens e serviços não promove justiça social nem protege efetivamente o consumidor, antes pelo contrário: reduz o investimento pelas empresas, diminui a oferta de emprego e torna desinteressante a produção de determinados produtos ou a prestação de serviços. E que a permanente tentação populista do tabelamento e do congelamento de preços foi responsável por mais de uma década de estagnação econômica do país.

Vale dizer: não se trataria sequer de medida adequada para os fins visados. Isto independentemente da vedação do excesso e da proporcionalidade em sentido estrito. Acrescente-se, por derradeiro, que além de figurar como parâmetro da possibilidade em tese do controle de preços, o princípio da razoabilidade será aplicado também para aferir a constitucionalidade dos termos de qualquer medida especificamente adotada, tendo em vista seus pressupostos e os rins que pretenda produzir.

Além de ser razoável, a intervenção estatal sobre os preços terá, em qualquer caso, de observar dois outros limites inequívocos. Um, de natureza conjuntural: a medida deve ser excepcional, para atender a circunstância específica e emergencial. $\mathrm{Na}$ ausência de uma situação anormal, fora do comum, não se legitima a providência, menos ainda com caráter duradouro. Vale dizer: o controle de preços jamais pode ser praticado como uma política pública ordinária.

Em outras palavras, o controle de preços poderá ser adotado temporária e excepcionalmente para formar um mercado privado e concorrencial, ou para reestabelecê-lo. Daí por diante, o mercado privado, devidamente organizado, passará a reger-se pela livre iniciativa e pela livre concorrência. Essa é a única hipótese em que o controle de preços pelo Estado poderá ser legítimo. Também este ponto de vista tem sido por mim sustentado de longa data, como se verifica da transcrição a seguir:

"Sem embargo, tanto o congelamento quanto o tabelamento serão inadmissiveis:

1. quando se prolonguem indefinidamente;

2. quando impuserem ao empresário a venda de seu produto abaixo do preço de custo.

No primeiro caso, a permanência do controle rígido de preços por período de tempo excessivamente longo rompe o caráter excepcional da medida e subverte os princípios da livre iniciativa e da livre concorrência. Tais princípios, como se demonstrou, não são absolutos e devem ser sopesados com outros. De outra parte, não podem ser anulados na prática. A razoabilidade da demora na volta ao regime de mercado será o critério do intérprete.

Quanto ao segundo caso, impor ao empresário a venda com prejuízo configura confisco, constitui privação de propriedade sem devido processo legal 
(art. $5^{\circ}$, LIV). E mais: é da essência do sistema capitalista a obtenção de lucro. $O$ preço de um bem deve cobrir o seu custo de produção, as necessidades de reinvestimento e a margem de lucro. O que é condenável e enseja a intervenção é o lucro arbitrário (art. 173, $\S 4^{\circ}$ ), o lucro abusivo, de cunho espoliativo." 46

Lembre-se mais uma vez que a existência de um mercado privado organizado não significa, naturalmente, que no seu âmbito não possam se desenvolver poderes econômicos, que conduzam a condutas anticoncorrenciais. A prática episódica do ilícito faz parte da normalidade. Para isso existem mecanismos próprios de punição e repressão ao abuso do poder econômico e ao aumento arbitrário de lucros, em consonância com a previsão genérica do art. $173, \S 4^{\circ}$ da Constituição.

O último pressuposto constitucional para reconhecer-se como legítimo o controle prévio de preços diz respeito ao seu conteúdo: jamais se poderá impor ao agente econômico praticar preços que não sejam capazes (i) de cobrir os seus custos porque haveria confisco - (ii) de propiciar um lucro mínimo apto a remunerar o dono do capital - porque seria a negação do regime de livre iniciativa - e (iii) de ensejar os reinvestimentos necessários, porque do contrário a atividade se inviabilizaria, frustrando o princípio da livre empresa.

A matéria já foi objeto de pronunciamento do Tribunal Constitucional italiano, consoante noticiado por Bruno Cavallo e Giampiero Di Plinio:

"Especificamente no que tange ao controle de preços, o Tribunal Constitucional italiano teve ocasião de julgar que ele se torna excessivo e, por consequinte, ilegítimo, quando penaliza os lucros empresariais, importando na imposição de preços não remunerativos ou tecnicamente desproporcionados aos custos de produção. A jurisprudência italiana ressaltou, por igual, a ilegitimidade de um sistema permanente de controle de preços, dada a natureza essencialmente conjuntural dessa medida de polícia." 47

Em conclusão: o controle prévio de preços poderá ser legítimo no sistema constitucional brasileiro diante de uma situação absolutamente anormal, de deterioração do mercado privado concorrencial, e não por qualquer outro fundamento. Seu propósito será o reestabelecimento do mercado livre, deverá se tratar de medida temporária e em nenhuma hipótese poderá impor preços inferiores ao preço de custo acrescido da margem necessária para reinvestimentos e de um lucro mínimo. E em todos os seus aspectos deverá observar o princípio da razoabilidade.

46 Luís Roberto Barroso, A crise econômica e o direito constitucional, in Revista Forense, 323-83 (1993).

47 Bruno Cavallo e Giampiero Di Plínio, Manuale di diritto pubblico dell'economia, Milão, 1983, p. 531, apud Fábio Konder Comparato, Regime constitucional do controle de preços no mercado, Revista de Direito Público 97, 1991, p. 25. 
1. Ao fim dessa exposição analítica - que se fez inevitavelmente longa - $e$ possível compendiar a essência das idéias desenvolvidas nas proposições seguintes:

2. A livre iniciativa é princípio fundamental do Estado e é da sua essência que os preços de bens e serviços sejam estabelecidos pelo mercado. Como consequiência, o controle prévio de preços não é admitido no ordenamento constitucional brasileiro como uma política pública regular.

3. O controle prévio de preços somente poderá ser legítimo diante da ocorrência de situação de anormalidade, de grave deterioração das condições de mercado, com ausência de livre concorrência e colapso da própria livre iniciativa. Aí a intervenção estatal se legitimaria pela necessidade de restabelecimento dos próprios fundamentos constitucionais da ordem econômica.

4. Mesmo quando possa ser excepcionalmente admitido, o controle prévio de preços está sujeito aos pressupostos constitucionais e sofre três limitações insuperáveis: a) deverá observar o princípio da razoabilidade, em sua tríplice dimensão: adequação lógica, vedação do excesso e proporcionalidade em sentido estrito; b) deverá ser limitado no tempo, não podendo prolongar-se indefinidamente; c) em nenhuma hipótese poderá impor a venda de bens ou serviços por preço inferior ao preço de custo, acrescido do lucro e do retorno mínimo compatível com o reinvestimento. 